\title{
Znaczenie judeochrześcijańskich korzeni i świadectwa chrześcijan o korzeniach żydowskich dla integralnego zrozumienia przestania biblijnego
}

\section{The Importance of Judeo-Christian Roots and of Christian Witness to the Jewish Roots for the Integral Understanding of the Biblical Message}

\begin{abstract}
Abstrakt: Punktem wyjścia artykułu są pierwotne napięcia pomiędzy wyznawcami judaizmu i chrześcijaństwa. Autor na ich tle ukazuje historyczny przełom we wzajemnych relacjach judeochrześcijańskich, który nastąpił po Soborze Watykańskim II. Umożliwił on wkroczenie judaizmu i chrześcijaństwa w drogę braterstwa i dialogu. W przekonaniu autora było to możliwe za sprawą wysiłków papieży (tj. Jana Pawła II, Benedykta XVI i Franciszka) oraz wspólnych instytucji i organizacji chrześcijańsko-żydowskich. Autor podkreśla również, że relacje chrześcijańsko-żydowskie cechuje wzajemne poszanowanie przy jednoczesnym zachowaniu własnej tożsamości i wierności swojej tradycji religijnej i duchowej. Na zakończenie artykułu zostały przedstawione osobiste doświadczenia autora w dialogu chrześcijańsko-żydowskim.
\end{abstract}

Słowa kluczowe: judaizm, Sobór Watykański II, chrześcijaństwo, Żydzi, dialog, Nostra aetate

Abstract: The starting point for the article are the primary tensions between Jews and Christians. Against that background, the Author shows the historic breakthrough in Judeo-Christian relations that happened after the Second Vatican Council. It enabled Judaism and Christianity to enter the path of brotherhood and dialogue. According to the Author, this was possible due to the efforts made by the popes (i.e. John Paul II, Benedict XVI and Francis) and joint Christian-Jewish institutions and organizations. The Author also emphasizes that Christian-Jewish relations are characterized by showing mutual respect while at the same time preserving their own identity and remaining faithful to their religious and spiritual tradition. The article ends with the presentation of the Author's personal experience with the Christian-Jewish dialogue.

Key words: Judaism, the Second Vatican Council, Christianity, Jews, dialogue, Nostra aetate 


\section{Kim są i skąd wzięli się judeochrześcijanie?}

Zarówno Chrystus, jak i wszyscy Apostołowie byli Żydami i ich ziemska działalność rozwijała się w łonie rabinizmu biblijnego. Respektowali przepisy Prawa, jak i zwyczaje, obrzędy i tradycje religii Mojżeszowej. Jednocześnie już w czasie ziemskiego życia Chrystusa właśnie na tle interpretacji Tory i ówczesnych praktyk religijnych dochodziło do ostrych polemik pomiędzy Jezusem a stronnictwami religijnymi, szczególnie faryzeuszami. W pierwszym okresie działalności Chrystusa wiązały się one ściśle zarówno ze świątynią w Jerozolimie, jak i z synagogą. Jednocześnie Chrystus nauczając przekraczał rabinacką interpretację, poszerzał ją i dopełniał, stawiając siebie na równi z Mojżeszem: Styszeliście, że powiedziano przodkom: (...) A Ja wam powiadam... (Mt 5,33). Jednak nie tyle samo nauczanie Jezusa, ile nowa świadomość mesjańska i synostwa Bożego w ścisłym tego słowa znaczeniu, doprowadziła w konsekwencji do podziału pomiędzy synagogą i Kościołem apostolskim. Słowa Chrystusa: Ja i Ojciec jedno jesteśmy (J 10, 30) - dla prawowitego Żyda były bluźnierstwem. Kościół, który powstał w dniu Pięćdziesiątnicy, składał się zarówno z Żydów jak i wiernych pochodzenia pogańskiego.

Wśród apostołów zarysowały się wyraźnie dwie grupy: judeochrześcijanie głównie jerozolimscy, skupieni wokół Piotra, Jana i Jakuba, Brata Pańskiego (por. Dz 9, 27; Ga 1, 19; 2, 9 i inne) oraz judeochrześcijanie w diasporze (Fenicja, Cypr, Antiochia Pizydyjska i inne), którym patronował Paweł i Barnaba, a później także św. Piotr.

Pomiędzy Żydami i judeochrześcijanami, którzy posługiwali się językiem hebrajskim lub aramejskim, a chrześcijanami pochodzenia pogańskiego, zwłaszcza po męczeństwie św. Szczepana, doszło do ostrego sporu (por. Dz 11, 19). W wyniku prześladowań, które wybuchły w Jerozolimie (Dz 8, 1-3), wyznawcy Chrystusa rozproszyli się najpierw po Judei i Samarii, a następnie także na Bliski Wschód (Damaszek, Cypr, Antiochia), i w krajach basenu Morza Śródziemnego (Macedonia, Listra, Derbe, Efez, Rzym).

Momentem decydującym dla młodej i zróżnicowanej wspólnoty Kościoła apostolskiego był tzw. Sobór Jerozolimski w roku 50. Uczestnicy tego zgromadzenia: Duch Święty, apostołowie i starsi wraz z całym Kościołem postanowili (Dz 15, 22), że etnikochrześcijanie, włączając się do Kościoła, nie muszą poddawać się obrzezaniu, a jedynie zachowywać wymagania przymierza Noachickiego (ofiary składane bożkom, zakaz krwi i tego, co uduszone). Od tego momentu Kościól judeochrześcijański, który odgrywał na początku ważną rolę w Kościele jerozolimskim, tracił stopniowo na znaczeniu. 
W wyniku prześladowań po II powstaniu Bar Kochby w roku 30, wielu zarówno Żydów jak i judeochrześcijan, rozproszyło się po Bliskim Wschodzie. Wreszcie począwszy od edyktu mediolańskiego w roku 313 za czasów Konstantyna Wielkiego, chrześcijan pochodzenia żydowskiego uznano za sektę żydowską, zniszczono także w dużym stopniu materialne i duchowe dziedzict wo judeochrześcijan. Dzisiaj trzeba je mozolnie odtwarzać, na podstawie nielicznych zachowanych pozostałości materialnych, głównie ossuaria z Jerozolimy i najbliższych okolic.

\section{Napięcia i spory w łonie judaizmu i w Kościele pierwszych wieków chrześcijaństwa}

W następstwie prześladowań ze strony Żydów (głównie ze strony judaizmu faryzejskiego), ale także Rzymian, którzy uznawali chrześcijan za sektę żydowską, wielu z nich opuściło Jerozolimę. Doszło do ostrego sporu pomiędzy judaizmem i chrześcijanami. Około roku 90, na tzw. synodzie w Jamnii (Jawne) nałożono na chrześcijan karę cheremu i uznano ich za sektę żydowską. Pojawiły się wówczas ostre oskarżenia w odniesieniu do Jezusa i Jego wyznawców. Cuda czynione przez Jezusa przypisywano czarnej magii, zaprzeczano nie tylko Jego zmartwychwstaniu, ale rozpowszechniano obraźliwe opinie, że Jezus był oszustem, heretykiem; że został ukrzyżowany za bałwochwalstwo, a bałwochwalcami są także wyznawcy Jezusa, którzy uznają Go za Boga (Syna Bożego) [Klinkowski 2011: 144-158].

Strona chrześcijańska nie pozostawała dłużna, kierowała ostre zarzuty przeciw Żydom. Spór ten znalazł swoje przedłużenie w dalszych wiekach, w okresie patrystycznym.

Justyn Męczennik (II w.) w swoim słynnym „Dialogu z Żydem Tryfonem” uznał, że wraz z rozpoczęciem Nowego Testamentu skończyła się religia Żydów, gdyż miejsce synagogi zajął Kościól, jako nowy Izrael. W twierdzeniu tym ma swoje źródło tzw. „teoria substytucji”, która obarcza wszystkich Żydów winą za śmierć Chrystusa i w dużym stopniu utrwaliła wrogi stosunek chrześcijan wobec Żydów.

Św. Augustyn zredukował rolę i wkład Żydów do zachowania ksiąg biblijnych dla chrześcijaństwa. Bóg zachował jednak Żydów jako „naród-świadka własnego grzechu i chrześcijańskiej prawdy”. Równie negatywnie postrzegał Żydów św. Jan Chryzostom, pisząc: "powołani do usynowienia, nadal pozostają w ciemnościach” [Podeszwa, Szczerbiński 2016: 176-177]. Ojcowie Kościoła przedstawiają judeochrześcijan z reguły jako sektę żydowską. 
Obie wspólnoty rozwijały się w skrajnej opozycji. W odpowiedzi na silny antychrystianizm Żydów, pośród chrześcijan rozwinął się i przez wieki panował skrajny antyjudaizm. Judaizm był uznawany za błędny, nieaktualny i zbyteczny. Obydwie religie przez wieki pozostawały w ostrym, wrogim antagonizmie wobec siebie. Na skutek napięć i wzajemnych oskarżeń judeochrześcijanie musieli się zadeklarować po jednej albo drugiej stronie. W wyniku rozwoju judaizmu rabinicznego z jednej strony i dominacji, a później zwycięstwa w Kościele etnikochrześcijan z drugiej strony, doszło po I Soborze w Nicei (325 r.) do całkowitej marginalizacji judeochrześcijan, którzy rozproszyli się po całym Bliskim Wschodzie.

\section{Historyczny przełom po Soborze Watykańskim II}

Deklaracja Nostra aetate Soboru Watykańskiego II znaczy faktyczny, „kopernikański” przełom Kościoła w stosunku do Żydów we wzajemnych relacjach judeochrześcijańskich. Zdaniem papieża Benedykta XVI „Sobór dał decydujący bodziec do tego, by z zaangażowaniem i w sposób nieodwołalny wejść na drogę dialogu, braterstwa i przyjaźni” [Benedykt XVI 2010: 17]. Deklaracja stwierdza między innymi, że Kościół wyrasta z religii Mojżesza, Patriarchów i Proroków, wspólnie z Żydami wyznajemy wiarę w jednego Boga, Pana nieba i ziemi, Żydzi nadal pozostają wybranym i umiłowanym narodem Boga, do nich należą przybrane synostwo, chwała, przymierze, nadanie Prawa, petnienie stużby Bożej i obietnice ( $\mathrm{Rz}$ 9, 4). Dokument potępia wszelkie formy prześladowania, dyskryminacji, akty nienawiści i antysemityzmu, które są zaprzeczeniem ewangelicznej miłości. Wreszcie wzywa do podjęcia braterskiego dialogu religijnego pomiędzy judaizmem i chrześcijaństwem w duchu wspólnego przykazania miłości (zob. Pwt 6, 4-6; Kpł 19, 18; Mt 22, 37-39) i uwzględnienia jedności Biblii bez przeciwstawiania Starego Testamentu Nowemu.

Teoretyczny dialog został dopełniony dialogiem życia i pamięci, najpierw przez papieży, a następnie także przez wspólne instytucje i organizacje chrześcijańsko-żydowskie. Faktem bez precedensu była pielgrzymka Pawła VI do Ziemi Świętej w styczniu 1964 r., a następnie także Jana Pawła II w marcu 2000 r., jego odwiedziny w Instytucie Yad Vashem i modlitwa przy zachodniej ścianie świątyni jerozolimskiej, a wcześniej - wizyta w Synagodze Większej w Rzymie, dnia 16 kwietnia $1986 \mathrm{r}$.

Papież Benedykt XVI, śladem Jana Pawła II, odwiedził również Ziemię Świętą wraz z Jerozolimą w maju 2009 r. (w tym Instytut Pamięci Yad Vashem) [Benedykt XVI 2009: 24], oraz synagogi w różnych krajach, do których pielgrzymował: w Kolonii (19 sierpnia 2005 r.), w Nowym Jorku (18.04.2008 r.) oraz w Rzymie (17.01.2010 r.). 
Drogą wzajemnego zbliżenia podąża także papież Franciszek ${ }^{1}$, kontynuując swoje bliskie, przyjacielskie kontakty z Żydami, które rozpoczął już w Argentynie (szczególnie z rabinem Abrahamem Skórką) [Bergoglio, Skórka 2013: 251]. Obecny papież również nawiedził także rzymską Synagogę Większą (17.01.2016 r.).

Na szerszej płaszczyźnie ten podwójny dialog jest prowadzony ze strony katolickiej przez ustanowioną przez papieża Pawła VI Komisję Stolicy Apostolskiej ds. Kontaktów Religijnych z Judaizmem, oraz przez instytucje chrześcijańsko-żydowskie, między innymi przez Międzynarodowy Katolicko-Żydowski Komitet Łączności (International Catholic-Jewish Liaison Committee, w skrócie: ILC) czy przez Międzynarodowy Komitet Żydowski ds. Konsultacji Międzyreligijnych (International Jewish Committee for Interreligious Consulatations, w skrócie: IJCIC ).

Wysiłki kolejnych papieży, zmierzające do pogłębienia wzajemnego lepszego zrozumienia i wspólnego świadectwa jako wyrazu wiary w jednego Boga stosownie do własnej tożsamości, znajdują swoje dopełnienie w dialogu i dokumentach Komisji Stolicy Apostolskiej ds. Kontaktów Religijnych z Judaizmem oraz Papieskiej Komisji Biblijnej, które stanowią organa pomocnicze w pełnieniu misji piotrowej papieża².

Ze strony Żydów nastąpiła również daleko idąca zmiana i zbliżenie do Kościoła katolickiego. Wymownym świadectwem tego jest oświadczenie rabinów ortodoksyjnych na temat chrześcijaństwa pt. „Czynić wolę naszego Ojca w niebie. Ku partnerstwu Żydów i chrześcijan”, z dnia 3.12.2015 r. W tym dokumencie czytamy między innymi: „Uznajemy, że od czasów II Soboru Watykańskiego oficjalne

${ }^{1}$ Wkład kolejnych papieży od Jana Pawła II do papieża Franciszka przedstawia bliżej ostatni dokument Komisji Stolicy Apostolskiej ds. Kontaktów Religijnych z Judaizmem Bo dary łaski i wezwanie Boże sa nieodwołalne $(\mathrm{Rz} 11,29)$ z 2015 r. [Komisja 2015: nr 8-11].

2 Dziełem Komisji Stolicy Apostolskiej ds. Kontaktów Religijnych z Judaizmem są dokumenty: Wskazówki i sugestie w sprawie wprowadzenia w życie deklaracji soborowej «Nostra aetate» (1.12.1974 r.), Żydzi i judaizm w głoszeniu Słowa Bożego i w katechezie Kościoła katolickiego. Wskazówki do właściwego przedstawiania tych zagadnień (24.06.1985 r.), Pamiętajmy! Refleksja na temat Szoah (16.03.1998 r.), Bo dary łaski i wezwanie Boże sa nieodwołalne (Rz 11, 29). Refleksja o kwestiach teologicznych odnoszacych się do relacji katolicko-żydowskich z okazji 50. rocznicy «Nostra aetate» (artykuł 4) (10.12.2015 r.). Znaczenie tych dokumentów dla relacji judeochrześcijańskich bliżej wyjaśnia dokument Bo dary łaski i wezwanie Boże są nieodwołalne... [Komisja 2015: nr 4-7]. Dopełnieniem wyżej przywołanych tekstów są dokumenty Papieskiej Komisji Biblijnej: Naród Żydowski i jego Święte Pisma w Biblii chrześcijańskiej (19.11.2001 r.) oraz Interpretacja Biblii w Kościele (23.04.1993 r.). 
nauczanie Kościoła katolickiego o judaizmie uległo głębokiej i nieodwracalnej przemianie" [Czajkowski 2016: 355]. W dalszym ciągu dokumentu można przeczytać między innymi: „Rozdzielając judaizm i chrześcijaństwo Bóg chciał rozdzielić partnerów, którzy w istotny sposób różnią się teologicznie, ale nie chciał, by byli oni wrogami". Przywołując świadectwo rabina Jaakowa Emdena, rabini stwierdzają: „Jezus przyniósł światu dwojakie dobro. Z jednej strony wspaniale umocnił Torę Mojżesza (...); Żaden z naszych mędrców nie podkreślał bardziej dobitnie nienaruszalność Tory. $Z$ drugiej strony usunął idole obecne pośród ludzi innych narodów, (...) i wszczepił w nich głęboko moralne zachowanie. (...) Chrześcijanie to społeczności, które działają w imię niebios, więc ich przeznaczeniem jest przetrwać; ich intencją jest działać w imię niebios, a nagroda nie będzie im odmówiona. (...) Gdy więc teraz Kościół katolicki uznał wieczne Przymierze między Bogiem a Izraelem, my Żydzi możemy uznać trwałą konstruktywną ważność chrześcijaństwa jako naszego partnera w zbawieniu świata, nie obawiając się, że będzie to wykorzystywane w celu nawracania" [Czajkowski 2016: 356].

„Żydzi i chrześcijanie mają wspólną wynikającą z Przymierza misję, aby doskonalić świat pod panowaniem Wszechmocnego - tak, by cała ludzkość wzywała Jego Imię, a ohydztwa były usunięte z powierzchni ziemi. (...) My Żydzi i chrześcijanie mamy więcej elementów wspólnych niż tych, które nas dzielą: etyczny monoteizm Abrahama, relację z Jedynym Stwórcą Nieba i Ziemi, który miłuje i troszczy się o każdego z nas, żydowskie Pismo Święte, przekonanie o wiążącej mocy tradycji, wartości życia, rodziny, współczującej prawości, sprawiedliwości, niezaprzeczalnej wolności, uniwersalnej miłości i ostatecznego pokoju w świecie” [Czajkowski 2016: 356].

W Polsce dialog z judaizmem prowadzi Komitet Episkopatu Polski ds. Dialogu z Judaizmem. Najbardziej widzialnym owocem dialogu chrześcijańsko-żydowskiego jest obchodzony od stycznia 1998 r., prawie we wszystkich większych miastach naszego kraju, Dzień Judaizmu. Ostatni, tegoroczny (2018 r.) XXI Dzień Judaizmu odbywał się pod hasłem: „Pokój! Pokój dalekim i bliskim” (Iz $57,19)$.

Nie ulega wątpliwości, że tak daleko sięgająca zmiana stosunku zarówno do Starego Testamentu, kryterium jego interpretacji, ale także do Żydów i judaizmu, jest konsekwencją genocidium, jakim było Szoah. Dokument Papieskiej Komisji Biblijnej stwierdza: „Wstrząs spowodowany przez eksterminację Żydów (Szoah) podczas II wojny światowej doprowadził wszystkie Kościoły do głębokiego 
przemyślenia swego stosunku do judaizmu i w konsekwencji do ponownego rozważenia swej interpretacji Starego Testamentu" [Papieska Komisja Biblijna 2002: 45].

\section{Jedność, ciągłość i wewnętrzny dynamizm ekonomii zbawienia}

Wyrażona w śródtytule prawda znajduje pełne oparcie w oficjalnym stanowisku Kościoła. Ostatni dokument Komisji Stolicy Apostolskiej ds. Kontaktów Religijnych z Judaizmem z 2015 r. stwierdza: „Glebą, która żywiła zarówno Żydów jak i chrześcijan był judaizm czasów Jezusa, który nie tylko wniósł walny wkład w chrześcijaństwo, ale także, po zburzeniu Świątyni w roku 70, w pobiblijny judaizm rabiniczny (...), który w swoim późniejszym rozwoju musiał polegać wyłącznie na modlitwie i interpretacji zarówno pisemnej, jak i ustnej Boskiego Objawienia. Tak więc Żydzi i chrześcijanie mają tę samą Matkę i mogą być postrzegani - tak, jak jest rzeczywiście - jako rodzeństwo, które (...) rozwinęło się w różnych kierunkach. Pisma starożytnego Izraela stanowią integralną część Pisma Świętego zarówno dla judaizmu i chrześcijaństwa, rozumianego przez obydwa jako Słowo Boże, historia Objawienia i zbawienia. (...) W pierwszych latach Kościoła byli więc tzw. judeochrześcijanie (Ecclesia ex circumcisione) i poganochrześcijanie (Ecclesia ex gentibus), jeden Kościół wywodzący się z judaizmu, a drugi od pogan, którzy jednak razem stanowili jeden jedyny Kościół Jezusa Chrystusa” [Komisja Stolicy Apostolskiej ds. Kontaktów Religijnych z Judaizmem 2016: 364-365].

Postulatem współczesnej biblijnej hermeneutyki wiary, dla nas chrześcijan, jest zatem odczytanie całego Pisma Świętego w kategoriach jedności i ciągłości skierowanych ku pełni. Jeden jest bowiem Boży plan zbawienia, który obejmuje całe dzieje biblijne, od stworzenia świata do Apokalipsy. Papież Benedykt XVI wyjaśnia ${ }^{3}$ : „Korzenie chrześcijaństwa znajdują się w Starym Testamencie i chrześcijaństwo zawsze czerpie z tych korzeni. Dlatego zdrowa nauka chrześcijańska zawsze odrzucała wszelkie odradzające się formy marcjonizmu, który na różne sposoby przeciwstawia Stary Testament Nowemu" [Benedykt XVI 2010: 40]. Interpretacja Nowego Testamentu z pominięciem tradycji oraz historycznego, kulturowego i religijnego podłoża, z którego wyrosła, będzie zawsze niepełna, często niezrozumiała albo nawet błędna [szerzej zob. Czajkowski 2013].

${ }^{3}$ Szerzej o relacji pomiędzy Kościołem a Izraelem zob. [Ratzinger 2004: 11-73] 
Celem zatem niniejszego artykułu jest z jednej strony ukazanie wielkiego przełomu, jaki w następstwie deklaracji Nostra aetate Soboru Watykańskiego II dokonał się w Kościele katolickim w stosunku do Żydów i objawienia Starego Testamentu. Z drugiej zaś strony artykuł pragnie ukazać jedność, komplementarność i ciągłość ekonomii zbawienia obydwu Testamentów, przy wzajemnym poszanowaniu różności i odrębności Tradycji judaistycznej i chrześcijańskiej.

Znana asymetria pomiędzy Starym i Nowym Przymierzem sprawia, że w tym względzie nie możemy liczyć na pełną akceptację ze strony naszych „starszych Braci” w wierze. Podobnie jak my, chrześcijanie, także Żydzi czytają swoje Święte Pisma w duchu własnej tradycji, zgodnie z przyjętymi od wieków zasadami interpretacji rabinicznej. Wzajemne poszanowanie tej odmienności oraz inności w relacjach do Nowego Testamentu może okazać się pożyteczne także dla judaizmu. Ostatecznie wiara w jednego Boga, Stworzyciela nieba i ziemi, i jedynego Pana dziejów, rozpowszechniła się na całym świecie właśnie dzięki chrześcijaństwu.

Przykład wzajemnego poszanowania, przy zachowaniu własnej tożsamości i odrębności interpretacji rabinicznej i chrześcijańskiej, daje sam papież Benedykt XVI w swojej książce pt. „Jezus z Nazaretu”. Znajdują się w niej fragmenty dialogu ze znanym uczonym rabinem Jacobem Neusnerem, autorem książki „Rabbi rozmawia z Jezusem"'. Benedykt XVI towarzyszy rabinowi Neusnerowi w jego dyskursie, wsłuchując się w nauczanie Jezusa. Obydwaj z zadowoleniem przyjmują fakt, że Jezus akcentuje wierność Boga w stosunku do siebie samego i wiary Izraela w słowach: Nie sadźcie, że przyszedłem znieść Prawo albo Proroków. Nie przyszedłem znieść, ale wypełnić. Zaprawdę bowiem powiadam wam: dopóki niebo i ziemia nie przemina, ani jedna jota, ani jedna kreska nie zmieni się $w$ Prawie, az się wszystko spetni (Mt 5, 17-18).

O ile powyższe słowa Chrystusa nie budzą zastrzeżeń Neusnera, to antytezy Chrystusa: Styszeliście, że powiedziano przodkom (...) a Ja wam powiadam..., podobnie jak kiedyś u żydowskich słuchaczy Jezusa, budzą wielkie zakłopotanie, zdumienie, a wręcz lęk. Jezus przemawia bowiem nie tylko jako Ten, który ma władzę (Mt 7,26), ale ośmiela się nawet mówić autorytetem i w imieniu samego Boga. To wydaje się żydowskiemu słuchaczowi niemożliwe do pojęcia, gdyż autorytet Jezusa stawia na jednej płaszczyźnie z wielkością Boga.

${ }^{4}$ Tytuł oryginału: A Rabbi talk with Jesus. An Intermillenial interfaith exchange (McGillQeen's University Press 2000). 
Papież podsumowując wspólne rozważanie z Rabinem na temat Kazania na Górze, stwierdza: „Neusner, wierzący Żyd i rabin, wzrastał w przyjaznych relacjach z katolickimi i ewangelickimi chrześcijanami, razem z chrześcijańskimi teologami wykłada na uniwersytecie i żywi głęboki szacunek do swych chrześcijańskich kolegów, jest jednak głęboko przekonany o prawomocności żydowskiej interpretacji Pisma Świętego. Szacunek dla wiary chrześcijańskiej i wierność wobec judaizmu skłoniły go do prowadzenia dialogu z Chrystusem. W swojej książce wmieszał się w tłum Jego uczniów na „Górze” w Galilei. Przysłuchuje się Jezusowi, porównuje Jego słowa ze słowami Starego Testamentu i z tradycjami rabinackimi, spisanymi w Misznie i Talmudzie. W dziełach tych rozpoznaje on ustną tradycję, sięgającą początków, które dają mu klucz interpretacyjny do Tory. Słucha, porównuje i rozmawia z samym Jezusem. Porusza go wzniosłość i czystość Jego wypowiedzi, a jednocześnie jest zaniepokojony nieusuwalną w jego oczach niespójnością, którą znajduje w najgłębszej warstwie Kazania na Górze. (...) Na koniec jednak decyduje się nie iść za Jezusem. Jak sam to określa, pozostaje przy wiecznym Izraelu" [Benedykt XVI 2007: 95-96].

„Neusner - zdaniem papieża Benedykta XVI - z wielkim lękiem i szacunkiem wspomina o tym tajemniczym utożsamianiu się Jezusa z Bogiem, widocznym w Jego słowach w Kazaniu na Górze, jednak jego analizy potwierdzają, że to właśnie jest punkt, w którym orędzie Jezusa różni się w sposób zasadniczy od wiary wiecznego Izraela. Różnicę tę wykazuje na przykładzie trzech najważniejszych przykazań, (...) dotyczące miłości rodziców, szabatu i świętości”. Rabin Neusner „dochodzi do niepokojącego dla siebie wniosku, że Jezus chce go odwieść od zachowania tych trzech podstawowych przykazań Bożych i skłonić do przyłączenia się do Niego" [Benedykt XVI 2007: 97]. W odpowiedzi na ten dylemat Benedykt XVI przedstawił chrześcijańską interpretację trzech kolejnych przykazań, a także ukazał Chrystusa jako żywą Torę - „Torę Mesjasza”, która jest czymś zupełnie nowym, innym, jest bowiem wypełnieniem Tory Mojżesza.

W osobach papieża Benedykta XVI i rabiego Neusnera otrzymaliśmy wymowny przykład postawy pełnej wzajemnego szacunku, która ukazuje z jednej strony komplementarny i dopełniający się charakter obydwu Testamentów.

Z drugiej strony, ponieważ obydwaj partnerzy dialogu zachowują swoją pełną tożsamość i wierność własnej tradycji religijnej, dialog staje się poważnym wyzwaniem, ukazując, że pojęcie Tory czy szerszej nauki Jezusa w Kazaniu na Górze, choć wyrasta ze Starego Testamentu, nie da się sprowadzić do wspólnego mianownika. 
Interpretacja tekstów nadal zachowuje swoją własną odrębność. Jednak jedni i drudzy rozumują i czytają Torę jak żywe słowo - dla Żydów jest nim słowo Mojżesza zawarte w Biblii, dla chrześcijan jest nim Słowo Wcielone - Jezus Chrystus.

Dla obydwu partnerów tego niesamowitego dialogu stanowi on pogłębienie i poszerzenie dotychczasowej, judaistycznej czy chrześcijańskiej interpretacji, która mimo swojej odrębności, zasługuje na pełny szacunek, chociaż nie wyraża się we wspólnej wierze. „Stosunek pomiędzy jednym i drugim Testamentem jest wzajemny: z jednej strony Nowy Testament wymaga, aby go czytano w świetle Starego, ale z drugiej strony zachęca równocześnie do „ponownego odczytania” Starego w świetle Chrystusa Jezusa (por. Łk 24, 45)” [Papieska Komisja Biblijna 2002: 39].

Zachowując wierność własnej tradycji religijnej i duchowej, w duchu Soboru Watykańskiego II, należy przede wszystkim szukać tego, co jest wspólne i co nas łączy. Motyw ten wielokrotnie powtarza się w oficjalnych dokumentach Kościoła. „Wzajemne poznawanie naszego duchowego dziedzictwa, uznanie tego, co nas łączy i poszanowanie w tym, co nas dzieli - stwierdza papież Franciszek - mogą prowadzić w przyszłości do dalszego rozwoju naszych stosunków, które powierzamy Bogu. Razem będziemy mogli wnieść wielki wkład w sprawę pokoju; razem będziemy mogli dawać świadectwo w szybko zmieniającym się świecie o trwałym znaczeniu Bożego planu stworzenia; razem będziemy mogli stanowczo przeciwstawiać się wszelkim formom antysemityzmu i różnym formom dyskryminacji” [Papież Franciszek 2014: 23].

\section{Komplementarność wiary obydwu Przymierzy}

Raz jeszcze pozwolę sobie odwołać się do słów papieża Franciszka: „Wyznanie chrześcijańskie znajduje swoją jedność w Chrystusie; Judaizm znajduje swoją jedność w Torze. Chrześcijanie wierzą, że Jezus Chrystus jest słowem Boga, które stało się ciałem w świecie; dla Żydów Słowo Boże jest obecne w Torze. Obie Tradycje wiary znajdują podstawę w Jedynym Bogu, Bogu Przymierza, który objawia się ludziom przez swoje słowo. Poszukując właściwej postawy wobec Boga, chrześcijanie zwracają się do Chrystusa jako źródła nowego życia, zaś Żydzi do Tory. (...) Judaizm i wiara chrześcijańska, jak widać w Nowym Testamencie, są dwoma sposobami, poprzez które lud Boży może sobie przyswoić Pisma Święte Izraela. Pisma, które chrześcijanie nazywają starym Testamentem, są zatem otwarte dla obydwu sposobów. Tak więc odpowiedź na Słowo Boże zbawienia, zgodna z jedną bądź drugą tradycją, może otworzyć dostęp do Boga pomimo, że od Jego zamysłu zbawienia zależy określenie, w jaki sposób ma On zbawić ludzkość w każdym 
przypadku" [Papież Franciszek 2015]. Komplementarność z równoczesnym zachowaniem jedności i odrębności wiary najpełniej ujawnia się w doświadczeniach tych, którzy wzorem Szawła, który po spotkaniu ze zmartwychwstałym Panem, staje się Pawłem (por. Dz 9, 1-5), noszą w sobie podwójną, żydowską i chrześcijańską świadomość i tożsamość. Doświadczyłem tego wielokrotnie w czasie spotkań z żywymi świadkami tej podwójnej tożsamości.

Przywołam tutaj najpierw dwa świadectwa o zasięgu ogólnoświatowym, mianowicie naczelnego rabina Rzymu z czasów II wojny światowej - Izaaka Zollera (Eugenio Zolli) oraz znanej powszechnie żydowskiej myślicielki Edyty Stein, późniejszej karmelitanki, a dziś świętej Teresy Benedykty od Krzyża, która podzieliła los milionów Żydów i została zamordowana w komorze gazowej Auschwitz-Birkenau. W doświadczeniu ludzi wyrosłych i wychowanych w religii i tradycji żydowskiej, którzy swoją pełnię odnaleźli w chrześcijaństwie, obydwa Testamenty nazywane przez nas Starym i Nowym, wieczystym Przymierzem (Łk 22, 20; Rz 11, 27) stanowią organiczną jedność i całość, wzajemnie się warunkują i dopełniają, tak dalece, że jedno bez drugiego zawsze jest fragmentaryczne i niepełne.

Rabin Zoller, nawet po swoim chrzcie św. mówił, że nie uważa się za Żyda nawróconego, lecz spełnionego, tak to uzasadniając: „Kościół stanowi ukoronowanie synagogi. Bo judaizm jest obietnicą, a chrześcijaństwo spełnieniem tej obietnicy. (...) Stary Testament jawił mi się w całości jako zaszyfrowany telegram Boga przesłany ludziom. Obecnie i kod, i szyfr to Chrystus, i właśnie w Jego świetle nabiera znaczenia mesjański dreszcz przebiegający przez wszystkie księgi Starego Przymierza” [Zolli 1999: 5-6]. Jako naoczny świadek Szoah podkreślał, że do jego zaistnienia przyczyniło się przekreślenie chrześcijańskich zasad przez ideologię faszystowską [www 2016].

Droga Edyty Stein - siostry Teresy Benedykty od Krzyża, była jeszcze bardziej dramatyczna. Poszukując Prawdy, została chrześcijanką i zakonnicą, a zginęła jak męczennica. Po raz pierwszy zbawczy wymiar krzyża Jezusa zajaśniał jej gdy, jeszcze jako ateistka odwiedziła swoją przyjaciółkę Gertrudę Reinach po śmierci jej męża. Była przekonana, że spotka ją załamaną i zrozpaczoną po stracie męża. Tymczasem pani Reinach przeżywała tę śmierć w duchu chrześcijańskiej wiary, we wspólnocie z Chrystusem ukrzyżowanym i w nadziei zmartwychwstania.

„Zbawienie płynące z krzyża i jego tajemnicze błogosławieństwo kładły się jakimś blaskiem na zbolałych rysach twarzy tej dostojnej kobiety. Edyta o nic ją nie 
pytała, ale wrażenie, które pozostało po przeżyciu, okazało się niezatarte. «Było to moje pierwsze zetknięcie się z krzyżem i jego boską mocą, jakiej udziela on tym, którzy go niosą. Po raz pierwszy widziałam naocznie zrodzony ze zbawczego cierpienia Chrystusa Kościół i jego zwycięstwo nad ościeniem śmierci. Był to moment, w którym moja niewiara załamała się, judaizm zbladł, a Chrystus zajaśniał: Chrystus w tajemnicy krzyża». To wyznanie, uczynione na piśmie pewnemu księdzu krótko przed swą śmiercią, siostra Benedykta zakończyła słowami: «Dlatego też przy obłóczynach mogłam wyrazić tylko jedno życzenie: by w zakonie nazywać się siostrą od Krzyża»" [s. Teresa Renata od Ducha Świętego 1987: 54-55].

Tylko w świetle odwiecznego zbawczego planu Boga można dostrzec, po ludzku całkowicie niezrozumiały, finał tego niezwykłego życia ateistki, Żydówki, męczennicy, chrześcijanki, karmelitanki, zakonnicy i świętej Kościoła katolickiego.

Z okazji jej beatyfikacji Jan Paweł II powiedział podczas homilii: „Była wielką córką narodu żydowskiego i wierzącą chrześcijanką pośród milionów niewinnie zamęczonych ludzi. (...) Jako Benedicta a Cruce (błogosławiona przez Krzyż) pragnęła wraz z Chrystusem nieść krzyż za zbawienie swego narodu, swego Kościoła, całego świata” [Jan Paweł II 1987]. To, co wydawało się niemożliwe, stało się rzeczywistością. Edyta Stein jest równocześnie „wielką córką Izraela i wierną córką Kościoła" [Jan Paweł II 1998].

Chciałbym także przywołać kilka wymownych świadectw z moich spotkań z Żydami lub chrześcijanami o korzeniach żydowskich, którzy w Jezusie uznali Syna Bożego i spełnienie nadziei i oczekiwań mesjańskich.

Jeszcze w okresie komunistycznym miałem radość prowadzić kilka pielgrzymek kapłanów do Ziemi Świętej. W programie pielgrzymki zadbałem o to, by każdorazowo miało miejsce spotkanie z karmelitą, ojcem Danielem Rufeisenem na Górze Karmel. Spotkanie i rozmowa z nim jako urodzonym Żydem, było ogromnie owocna i w sposób zasadniczy poszerzała i pogłębiała chrześcijańskie zrozumienie żydowskości Jezusa i trwałości obietnic danych Izraelowi jako wybranemu narodowi Boga (por. Ga 6, 16). Ponadto ukazywała jednostronność, a wręcz błędność szeroko rozpowszechnionej w Kościele katolickim „teorii substytucji”, według której Kościół zastąpił dawnego Izraela, wszyscy Żydzi są współwinni śmierci Chrystusa. Spotkania ojcem Rufeisenem były faktycznie realizacją postulatu deklaracji Nostra aetate, który nakazuje, aby „na poziomie praktycznym, 
szczególnie chrześcijanie powinni się starać lepiej rozpoznać fundamentalne składniki religijnej tradycji judaizmu oraz dowiedzieć się, w jakich zasadniczych rysach definiują siebie sami Żydzi w przeżywanej przez siebie tradycji religijnej” (Preambuła). Spotkanie i bezpośrednia rozmowa z urodzonym Żydem pozwoliła również pogłębić świadomość znaczenia Zagłady Żydów.

Rozmowy z ojcem Danielem budziły z reguły ostrą reakcję, a wręcz sprzeciw braci kapłanów, ale - jak mogłem się przekonać - okazały się bardzo owocne i przyczyniły się znacznie do pogłębienia wszystkich poruszanych problemów.

Osobiście również wiele zawdzięczam moim licznym kontaktom z Żydami. Szczególnie wdzięcznie wspominam spotkanie z panem Józefem Lichtenem w ramach przygotowań do kolokwium chrześcijańsko-judaistycznego w Krakowie-Tyńcu, w maju 1987 r. Spotkałem się z nim w gabinecie redaktora Jerzego Turowicza. Urzekł mnie swoją osobistą, głęboką kulturą i znajomością nie tylko teologii chrześcijańskiej, ale także realiów życia Stolicy Apostolskiej, od lat mieszkał bowiem w Rzymie i znał wszystko z własnego doświadczenia. Wychodząc od pana Turowicza, pytałem: „Czy to naprawdę jest pan Lichten, który reprezentuje Ligę Przeciw Zniesławieniu Żydów?”. Pan Turowicz oczywiście potwierdził. Nie ukrywam, że trudno mi było w to uwierzyć.

Wymieniliśmy numery telefonów i prosił, abym przy najbliższej okazji pobytu w Rzymie odwiedził go. Mnie również bardzo na tym zależało. Kiedy w grudniu tego samego roku pojechałem do Rzymu na spotkanie Komisji ds. Kontaktów Religijnych z Judaizmem, zatelefonowałem do państwa Lichtenów. Małżonka pana Lichtena oznajmiła mi krótko: „Niestety, Józef nie żyje. Pogrzeb odbędzie się jutro". Skontaktowałem się natychmiast z ówczesnym biskupem (dziś kardynałem) Jorge Mejia oraz z ówczesnym sekretarzem tejże Komisji, ks. Pierfrancesco Fumagallim. Razem uczestniczyliśmy w pogrzebie. Biskup Mejia poprosił obecnych tam rabinów, abyśmy trzej mogli nad trumną odmówić psalm De profundis, recytowany bądź śpiewany na pogrzebach katolickich. Rabini się zgodzili pod jednym wszakże warunkiem, tym mianowicie, że na koniec psalmu nie dodamy: Chwała Ojcu....

Przed laty w seminarium ojciec duchowny prosił nas, alumnów, abyśmy na zakończenie każdego psalmu w brewiarzu przynajmniej pobożnie odmawiali Chwała Ojcu.... W miarę możliwości starałem się spełniać jego polecenie. Nad trumną pana Lichtena uświadomiłem sobie, że nie jest to tylko końcówka Psalmu, 
a wyrażenie najgłębszej istoty chrześcijaństwa. Odtąd, gdy prywatnie sławię Trójcę Świętą, zawsze odmawiam trzy razy tę właśnie modlitwę na cześć Ojca, Syna i Ducha Świętego [szerzej zob. Muszyński 2015: 114-115].

Równie wdzięcznie i serdecznie wspominam moje jedyne, niezwykłe spotkanie ze znanym pisarzem, tłumaczem Biblii, poetą żydowskiego pochodzenia, Romanem Brandstaetterem. Było to $\mathrm{w}$ gruncie rzeczy spotkanie całkiem przypadkowe, w Wiedniu, w Stephanushaus, gdzie zatrzymałem się na nocleg. Kiedy się dowiedziałem, że także państwo Brandstaetterowie nocują w tym samym miejscu, poprosiłem o spotkanie z panem Brandstaetterem. Bardzo szybko zorientowałem się, że łączy nas jedna miłość do Biblii i ziemskiej ojczyzny naszego Pana. Skorzystałem z okazji i wyraziłem swój podziw nie tylko dla dzieła „Jezus z Nazaretu”, ale także dla tłumaczenia Psalmów i innych ksiąg biblijnych oraz dla piękna tworzonej przez niego poezji. Znajomość realiów biblijnych i dziejów Ziemi Świętej przez pana Brandstaettera była naprawdę imponująca. W nawiązaniu do licznych dzieł pisanych, powiedziałem, że tak pisać może tylko ktoś, kto jest prawdziwym Żydem, chrześcijaninem i poetą.

Nie omieszkałem zaświadczyć, że często korzystam z tłumaczenia Psalmów pana Brandstaettera i zacytowałem nawet z pamięci kilka wersetów „Hymnu do Biblii”, mówiąc: „Panie Profesorze, ten hymn nie powstał bez natchnienia Ducha Świętego”. Gdy przypomniałem słowa: „człowiek pewien, który był Ojczyzną Boga, skazał Go na wygnanie...”, pochodzące z wiersza pt. „Przypowieść o ojczyźnie” Brandstaetter był głęboko wzruszony - i nie waham się powiedzieć - szczęśliwy.

Kiedy dowiedział się, że w latach 1965-1967 studiowałem w Jerozolimie i przeżyłem tam wojnę sześciodniową w 1967 r., wypytywał o wiele szczegółów, co zmieniło się w ojczyźnie ziemskiej naszego Pana od czasów II wojny światowej, jak aktualnie wyglądają stacje drogi krzyżowej. Ja natomiast, w nawiązaniu do znanej z „Kręgu biblijnego” „nocy biblijnej”, ośmieliłem się zapytać „O spotkanie z rabbim Nikodemem" i o przeżycia związane z reprodukcją przedstawiającą oblicze Chrystusa w Klasztorze w Dolinie św. Krzyża. Z żywym przejęciem pan Brandstaetter dzielił się dodatkowymi szczegółami tego jedynego w swoim rodzaju doświadczenia, które ja znałem tylko ogólnie z „Kręgu biblijnego”.

Jeden temat biblijny wywoływał drugi. Rozmowy i wspomnienia z jednej i drugiej strony nie miały końca. Około północy pan Brandstaetter powiedział: „Pójdę przeprosić żonę, że przyjdę później" i rozmowy ciągnęły się do późna w nocy 
[szerzej por. Muszyński 2002: 147-153]. Jedno spotkanie, ale niezapomniane, z którego niesłychanie wiele się nauczyłem.

Pan Brandstaetter potrafił powiedzieć: „ludzie się dziwią, że ja zrobiłem z Jezusa Żyda. Dla mnie to powiedzenie ilustruje dramatyczną sytuację. Dramatyczną w tym sensie, że ilustruje, jak chrześcijaństwo oddaliło się od swych korzeni, że właśnie taka prezentacja Jezusa ludzi szokuje. Nas nie szokuje, bo my jesteśmy z tymi zagadnieniami oswojeni” ${ }^{5}$. Z pokorą przyznaję, że brak nam niestety tej podwójnej wrażliwości i głębi, którą posiadają ludzie z żydowskimi korzeniami.

Doświadczyłem tego wielokrotnie także w łączności z innymi przedstawicielami zarówno Żydów jak i tych, którzy mają korzenie żydowskie, ale wzorem Szawła, spotkali Chrystusa zmartwychwstałego (por. Dz 9, 5). Przywołam tutaj cztery postaci: kardynała Jean Marii Lustigera, amerykańskiego rabina Byrona Sherwina, księdza infułata Grzegorza Pawłowskiego, a także profesora Jana Grosfelda. Z wszystkimi łączyły mnie lub łączą bliskie, serdeczne relacje.

Spotykałem się kilkakrotnie z kard. Lustigerem przy różnych okazjach, także w jego rezydencji w Paryżu. Dzięki tym spotkaniom mogłem się przekonać, co znaczy być jednocześnie Żydem i chrześcijaninem, i dźwigać w sobie podwójne dziedzictwo i podwójną tożsamość. Mówił: „Urodziłem się Żydem i nim zostanę, nawet jeśli rabini mają na ten temat inne zdanie. Kiedy stałem się chrześcijaninem, nie przestałem przecież nadal być Żydem ani dla ówczesnego rządu, ani dla hitlerowców. Nigdy nie odrzuciłem żydowskiego losu, jaki otrzymałem od matki” [www 2018]. Był w pełni świadomy, że dla wielu Żyd i chrześcijanin to rzeczywistość przeciwstawna. Świadczy o tym między innymi następująca wypowiedź: „Wiem, że jestem żywą prowokacją, która zmusza do zastanawiania się nad historyczną postacią Mesjasza. Dzięki mojej historii jestem nosicielem jakiejś cząstki tej postaci. Ta prowokacja jest dla Kościoła zbawienna. Niezależnie od mojego przypadku, niezależnie od mojej osoby" [www 2018].

Właśnie ta bogata, żydowsko-chrześcijańska osobowość kard. Lustigera, w sposób niezmiernie głęboki poszerzała także mój osobisty horyzont myślenia i pozwalała lepiej rozumieć złożony problem dialogu chrześcijańsko-judaistycznego. Zwłaszcza w trudnym okresie kontrowersji związanych z Karmelem w Oświęcimiu świadomość

5 Wspomnienie dr hab. Izabeli Jaruzelskiej, w: Świat Biblii Romana Brandstaettera (1999:280). 
polskich korzeni Kardynała pozwalała mi liczyć na jego zrozumienie. Wiadomo bowiem, że rodzice kard. Lustigera wyemigrowali za granicę z Będzina na Śląsku.

Amerykański rabin Byron L. Sherwin byłgodnym uczniem wielkiego rabina Abrahama J. Heschela, którego nazywał swoim „nauczycielem i mistrzem”. Jako potomek Żydów, którzy przez 500 lat zamieszkiwali w Polsce, był żywo zainteresowany judaizmem wschodnim, a szczególnie pobożnością, praktykami chasydów na dawnych ziemiach polskich. Miałem okazję przygotować z nim, przy czynnym współudziale kardynała Józefa Bernardina i dra Howarda A. Sulkina, przewodniczącego Institute of Jewish Studies of Judaica $w$ Chicago, seminarium letnie dla profesorów i wykładowców seminariów w Polsce w 1989 r. Dla większości, jeżeli nie dla wszystkich, był to pierwszy kontakt z żywą wspólnotą, religijnością i praktykami Żydów 6 .

Zostawił po sobie bogatą spuściznę literacką [Sherwin 1995, 2002, 2003, 2005], która stanowi cenne źródło do poznania duchowości, myśli religijnej, praktyk i pobożności chasydów. Podjął również ciekawą, ale i polemiczną propozycję połączenia żydowskich poglądów, twierdząc, że Jezus był fałszywym Mesjaszem, któremu się nie powiodło, z chrześcijańską prawdą o Mesjaszu Dawidowym. Jego zdaniem: „Czas już, aby chrześcijanie uznali Jezusa za Żyda, a Żydzi odzyskali Go jako pełnoprawnego i czcigodnego członka ludu żydowskiego, jako naszego brata”. Wysunął także „propozycję, aby Jezusa uznawano za jednego z żydowskich Mesjaszy, to jest za syna Józefa. To dałoby Mu miejsce w ramach żydowskich rozważań teologicznych i zakończyłoby ciągnącą się przez stulecia tradycję faktycznej ekskomuniki Jezusa ze wspólnoty wiary, do której należał. Przyznałoby Mu to rolę w żydowskiej teologii i byłaby to rola mesjańska" [Sherwin 2013: 14, 17].

Jeszcze ciekawszy jest jego osobisty punkt widzenia, który zdradza jak głęboko związany jest z polską, chasydzką tradycją. „Mnie, który wyrosłem w latach po Holokauście i znałem los polskich Żydów, nie można się chyba dziwić, że myślałem o Jezusie jako o polskim Żydzie. Kiedy byłem dzieckiem, wiedziałem, że Jezus zmarł straszliwą śmiercią i wiedziałem, że miliony polskich Żydów zginęły okropną śmiercią. Jako dziecko słyszałem nawet jak Hitlera nazywano antychrystem i porównywano do Poncjusza Piłata. Zatem ponieważ byłem dzieckiem, wyobrażałem sobie Jezusa ubranego jak polski Żyd i żyjącego jak polski Żyd. Takie wyobrażenie Jezusa można odnaleźć również w sztuce dwu największych żydowskich

${ }^{6}$ Owocem letniego seminarium Spertus College of Judaica jest książka Dzieci jednego Boga, Warszawa 1991, s. 418. 
artystów, pochodzeniem związanych z Polską: Marca Chagalla i Maurycego Gottlieba" [Sherwin 2013: 19].

Bardzo szczególną osobą jest kapłan archidiecezji lubelskiej, ksiądz infułat Grzegorz Pawłowski, urodzony w Polsce, w żydowskiej rodzinie jako Jakub Hersz Griner, ocalony przez siostry zakonne i polskie rodziny w okresie wojny. Arcybiskup Józef Życiński nazywał go „człowiekiem trzech ojczyzn”. Jedną z nich stanowi tradycja żydowska, z którą zapoznał się jako mały chłopiec, i z którą się identyfikuje, drugą jest Polska, gdzie odnalazł swoje powołanie do służby Bogu Abrahama i Jezusa, trzecią stało się państwo Izrael, gdzie od 1970 r. pełni posługę duszpasterską w Jaffie. Wyznał: „Chrystus Pan stawał mi się coraz bardziej bliski. Zacząłem rozumieć, że On jest tym obiecanym Mesjaszem. Jeżeli jest obiecanym Mesjaszem, to jest tym, na którego naród żydowski czeka! A więc na co, na kogo miałbym jeszcze czekać? (...) Dla mnie droga, która przeszedłem, to jest wypełnienie religii żydowskiej, to jest dalszy ciąg! (...) Chrześcijaństwo jest dla mnie ubogaceniem, wypełnieniem Starego Testamentu” [Montusiewicz 2005: 101-102].

W ten szereg postaci o korzeniach żydowskich wpisuje się znakomicie także profesor Jan Grosfeld. Osobiście wspominam go wdzięcznie jako członka najpierw Podkomisji, a później Komisji Episkopatu Polski ds. Dialogu z Judaizmem, z pierwszego - nie waham się powiedzieć - pionierskiego okresu tego dialogu. Wśród ostrych polemik, które dotyczyły między innymi sporu wokół Karmelu oświęcimskiego, można było zawsze liczyć na jego zrównoważony osąd człowieka o podwójnej, a może i potrójnej, żydowsko-chrześcijańskiej i polskiej tożsamości.

Wśród takich tematów, jak: judeochrześcijańska koncepcja człowieka, wybór, powołanie, przymierze, Kościół i judaizm, zawsze wyraża głębię i pełnię wiary, uwzględniającej jedność i ciągłość Bożego Objawienia w wymiarze dynamicznym i progresywnym, skierowanym ku pełni Bożego Objawienia, którą wskazał nam sam Chrystus. To właśnie On w drodze z uczniami do Emaus wyjaśniał im, zaczynajac od Mojżesza poprzez wszystkich proroków, co we wszystkich Pismach odnosiło się do Niego (Łk 24, 27). Jako ekonomista i politolog, prof. Grosfeld nie zacieśnia z reguły swoich rozważań wyłącznie do wymiaru biblijnego, ale poszerza problematykę także o aktualny wymiar społeczny, a wręcz polityczny.

Dla ilustracji pozwolę sobie przywołać dwie znamienne wypowiedzi, z których pierwsza dotyczy wybrania Izraela, druga wskazuje na konieczność odkrywania żydowskich korzeni chrześcijaństwa: „Historyczne doświadczenie wiary, przeżycie 
obecności Boga miało miejsce pośród Żydów, nie w jakimkolwiek innym narodzie. (...) Jest to jedyny naród wybrany ze względu na inne narody. Wybór ten został zapoczątkowany przez Najwyższego w konkretnej osobie, Abrahamie, pasterzu aramejskim, i kontynuowany - zgodnie z daną obietnicą (...).

Historia zbawienia nie kończy się na samej historii żydowskiej. Abrahamowi Bóg powiedział bowiem: $w$ twoim potomstwie będa błogosławione wszystkie narody ziemi. Nie jakiś inny naród, lecz wszyscy ludzie, poganie. Objawienie ma charakter progresywny i znajduje swoją kulminację w kolejnym, tak potężnym przejściu Boga Jedynego, jakie dokonało się w Jezusie Chrystusie. Rozszerzonym ludem Boga - lecz nie narodem - ludem wybranym, staje się Kościól, zgromadzenie chrześcijan. Jak mówi Sobór Watykański II, ma on być lumen gentium, światłem na oświecenie pogan, narodów. Skoro Żydzi nie są poganami, to ich droga z Bogiem jest odrębna. Pan zachowuje ich dla siebie w inny sposób, a co będzie w przyszłości - tego nie wiemy. I takie jest dziś oficjalne nauczanie Kościoła katolickiego w kwestii Żydów i judaizmu. (...) Tymczasem Żyd na zawsze pozostaje tym, który pierwszy usłyszał słowo Boga Jedynego i poszedł za Nim. Żadne niewierności Żydów nie mogą tej drogi i tego przymierza zniweczyć, nie mogą zdezaktualizować wybrania Żydów przez duże „Ż”, gdyż jego gwarantem całkowitym i jedynym jest sam Bóg, a nie naród wybrany" [Grosfeld 2011: 38-39; por. Grosfeld 1998: 148-149].

Niezmiernie trafnie prof. Grosfeld wyraża także ciągłość i komplementarność obydwu Przymierzy i wypływającą z tego jedność wiary, w słowach: „Odrzucenie żydowskich korzeni naszej wiary jest wyparciem się całej historii Boga z ludźmi, ba, samego Boga i Jego planu, który w historii się realizuje. Byłoby więc równoznaczne z odrzuceniem tego, czego każdy z nas najbardziej potrzebuje, miłości, bo sami dać jej sobie nie możemy. Chrześcijanin negujący żydowski korzeń swojej wiary, odrzuca krzyż i samego Sługę cierpiącego Jahwe, który - jak mówi Izajasz - nie dał głosu protestu, i jak baranek dał się prowadzić na śmierć. Wiedział, że tam właśnie czeka Ojciec ze swą stokrotna nagrodą" [Grosfeld 1996: 5].

Ukazując tak wyraźnie i jednoznacznie jedność i ciągłość obydwu Testamentów, w niczym nie zamazuje czy umniejsza istniejących przy tym różnic w judaizmie i chrześcijaństwie. Jestem przekonany, że tak potrafi mówić tylko ktoś, kto dźwiga w sobie podwójną tożsamość i wiążącą się z tym podwójną świadomość i wrażliwość. Za takie całościowe ujęcie treści wiary chrześcijańskiej należą się Panu Profesorowi serdeczne słowa szczególnej wdzięczności. Jednocześnie w pokorze 
ducha przyznaję, że w tym względzie właśnie my, chrześcijanie, mamy jeszcze wiele do nadrobienia.

Takie spojrzenie na komplementarność, jedność i ciągłość obydwu Przymierzy nie jest dzisiaj już niczym nowym. Oddaje ono wiernie aktualny stan wzajemnych, chrześcijańsko-żydowskich relacji. Świadczyć mogą o tym między innymi wypowiedzi papieża Franciszka, które mogą stanowić podsumowanie przedstawionych relacji: „Jestem przekonany, że to, co dokonało się w ciągu ostatnich dekad w stosunkach miedzy Żydami a katolikami, jest autentycznym darem Boga, jednym z cudów, jakich On dokonał, za które powinniśmy błogosławić Jego Imię: Chwalcie Pana nad panami, bo Jego łaska na wieki. On sam cudów wielkich dokonał, bo Jego łaska na wieki (Ps 136, 3-4). Był to dar od Boga, który jednak nie mógłby się objawić bez zaangażowania wielu osób, odważnych i wielkodusznych, zarówno Żydów, jak i chrześcijan” [Franciszek 2014: 22].

„Z pomocą Boga, przede wszystkim począwszy od Soboru Watykańskiego II, odkryliśmy na nowo, że naród żydowski jest dla nas wciąż świętym korzeniem, z którego wyrósł Jezus. Ja również, w przyjaźni z braćmi Żydami, którą przez wszystkie lata pielęgnowałem $\mathrm{w}$ Argentynie, wielokrotnie zadawałem pytanie Bogu w modlitwie. Zwłaszcza wtedy, gdy na myśl i pamięć nasuwały się straszliwe doświadczenia Szoah. Podobnie jak Paweł Apostoł, nigdy nie przestał być wierny przymierzu zawartemu z Izraelem, pośród straszliwych prób tych stuleci, Żydzi zachowali swoją wiarę w Boga. I za to nigdy nie będziemy im wystarczająco wdzięczni jako Kościól, ale także jako ludzkość. Oni też, właśnie trwając w wierze Boga Przymierza, przypominają wszystkim, również nam, chrześcijanom, fakt, że jako pielgrzymi wciąż oczekujemy na powrót Pana, toteż zawsze musimy być na Niego otwarci i nigdy nie możemy kryć się za tym, co już osiągnęliśmy" [Franciszek 2017: 25-26]. 


\section{Bibliografia:}

A Rabbi talk with Jesus. An Intermillenial interfaith exchange (2000) McGill-Qeen's University Press.

Benedykt XVI (2010), Przemówienie w rzymskiej Synagodze Większej, ORP 3-4.

Benedykt XVI (2010), Posynodalna adhortacja apostolska Verbum Domini.

Benedykt XVI (2009), Przemówienie w Instytucie Pamięci Yad Vashem, ORP 7-8.

Benedykt XVI (2007), Jezus z Nazaretu cz. 1, Kraków.

Bergoglio J., Skórka A. (red.) (2013), W niebie i na ziemi, Kraków.

Boniecki A., (2007), Żydowski kardynat, Tygodnik Powszechny 33/2007, (18.08.2007), http://www.dialog.org/dialog_pl/lustiger.html [dostęp dnia: 28.05.2018].

Czajkowski M. (2016), Czy Żydzi mają diabła za ojca?, Warszawa.

Czajkowski M. (2013), Nowy Testament a judaizm, Wrocław.

Franciszek, List do Eugenio Scalfariego z 11.09.2013 r., w: Białek B., Borto P. (2017), Co Kościót myśli o Żydach i judaizmie? Co Żydzi myśla o Kościele?, Kielce.

Franciszek (2015), Przemówienie do członków Międzynarodowej Rady Chrześcijan i Żydów, 30.06.2015, w: Bo dary łaski i wezwanie Boże sa nieodwołalne, nr 24.

Franciszek (2014), Przemówienie podczas spotkania z Naczelnymi Rabinami Izraela, 26.05.2014 r., ORP 6.

Gądecki S. (1991), Dzieci jednego Boga, Warszawa.

Grosfeld J. (2011), Od lęku do nadziei. Chrześcijanie, Żydzi, świat, Kraków.

Grosfeld J. (1999), Krzyż i gwiazda Dawida, Warszawa.

Grosfeld J. (1998), Wybranie przez duże „Ż”, w: Chrostowski W. (red.), Ja jestem Józef, brat wasz. Księga pamiątkowa ku czci abp. Henryka J. Muszyńskiego, Warszawa.

Jan Paweł II (1998), Homilia podczas Mszy św. kanonizacyjnej bł. Teresy Benedykty od Krzyża, Rzym, 17.10.1998, http://www.benedykta.diecezja.gda.pl/content/homiliajana-pawla-ii-podczas-mszy-sw-kanonizacyjnej.pdf [dostęp dnia: 10.05.2018].

Jan Paweł II (1987), Homilia podczas Mszy św. beatyfikacyjnej Edyty Stein, Kolonia, 1.05.1987, w: Ptasznik P. (red.) (2008), Dzieła zebrane, t. XI, Kraków.

Klinkowski J. (2011), Narodziny chrześcijaństwa w judaizmie, Communio 3.

Komisja Stolicy Apostolskiej ds. Kontaktów Religijnych z Judaizmem (2015), Bo dary łaski $i$ wezwanie Boże sq nieodwołalne $(R z 15,29)$. Refleksja o kwestiach teologicznych odnoszacych się do relacji katolicko-żydowskich z okazji 50. rocznicy "Nostra aetate» (artykuł 4), 10.12.2015 r.

Komisja Stolicy Apostolskiej ds. Kontaktów Religijnych z Judaizmem (1998), Pamiętajmy! Refleksja na temat Szoah, 16.03.1998 r.

Komisja Stolicy Apostolskiej ds. Kontaktów Religijnych z Judaizmem (1985), Żydzi i judaizm w głoszeniu Słowa Bożego i w katechezie Kościoła katolickiego. Wskazówki do właściwego przedstawiania tych zagadnień, 24.06.1985 r.

Komisja Stolicy Apostolskiej ds. Kontaktów Religijnych z Judaizmem (1974), Wskazówki $i$ sugestie $w$ sprawie wprowadzenia $w \dot{z} y c i e$ deklaracji soborowej "Nostra aetate”, 1.12.1974 r.

Muszyński H. J. (2015), Początek wspólnej drogi, Gniezno-Pelplin.

Muszyński H. J. (2002), Spotkanie, w: Nie zapomnimy. Świadkowie życia i czytelnicy o Romanie Brandstaetterze, Poznań 2002.

Montusiewicz L. (2005), Sługa Mesjasza, Lublin. 
Nawrócenie głównego rabina Rzymu, 23.05.2016, https://milujciesie.org.pl/nawrocenieglownego-rabina-rzymu.html [dostęp dnia: 2.05.2018].

Papieska Komisja Biblijna (2002), Naród żydowski i jego Święte Pisma w Biblii chrześcijańskiej, nr 22, Kielce.

Podeszwa P., Szczerbiński W. (red.) (2016), Co katolik powinien wiedzieć o judaizmie, Poznań.

Ratzinger J. (2004), Wielość religii i jedno Przymierze, W Drodze, Poznań.

Sherwin B. L. (2013), A wy za kogo mnie uważacie? Żydowska odpowiedź na pytanie Jezusa, Znak nr 701.

Sherwin B. L. (2005), We współpracy z Bogiem. Wiara, duchowość i etyka społeczna Żydów, Kraków.

Sherwin B. L. (2002), Jan Paweł II i dialog międzyreligijny.

Sherwin B. L. (2003), Abraham Joshua Heschel, Kraków.

Sherwin B. L. (1995), Duchowe dziedzictwo Żydów polskich, Warszawa 1995.

Świat Biblii Romana Brandstaettera (1999), Ogólnopolska Interdyscyplinarna Sesja Naukowa 20-22.10.1999 w UAM w Poznaniu, Szczecin.

Teresa Renata od Ducha Świętego, s. (1987), Edyta Stein, filozof i karmelitanka, Paryż. Zolli E. (1999), Przed świtem, Warszawa-Katowice. 